\title{
PENINGKATAN KETERAMPILAN MENULIS PANTUN DAN \\ SYAIR DENGAN MODEL CONTEXTUAL TEACHING AND \\ LEARNING SISWA KELAS V MI MA'ARIF CANDRAN GODEAN
}

\section{Isniarni}

Fakultas Ilmu Tarbiyah dan Keguruan, UIN Sunan Kalijaga Yogyakarta Email: isniarni.ha@gmail.com

\begin{abstract}
ABSTRAK
Penggunaan metode, strategi dan pendekatan yang relevan dalam pembelajaran sangat dibutuhkan, termasuk penggunaan model pembelajaran Contextual Teaching and Learning (CTL) pada mata pelajaran Bahasa Indonesia dalam peningkatan keterampilan menulis pantun dan syair siswa kelas V di MI Ma'arif Candran Godean tahun pelajaran 2016-2017.
\end{abstract}

Penggunaan pembelajaran Contextual Teaching and Learning (CTL) memiliki potensi untuk mengembangkan ranah pengetahuan dan keterampilan proses dan mengembangkan sikap, nilai serta kreativitas siswa dalam memecahkan masalah yang terkait dengan kehidupan mereka sehari-hari, melalui interaksi dengan sesama teman dan juga mengembangkan keterampilan sosial.

Hambatan-hambatan pembelajaran melalui model kontekstual dalam menulis pantun diantaranya siswa kesulitan dalam menyusun kalimat dalam baris pantun baik yang berupa sampiran maupun isi yang sesuai tema, dalam bekerja kelompok hanya didominasi oleh siswa yang mempunyai keterampilan menulis yang potensi lebih tinggi, siswa kurang berani mengeluarkan pendapat dalam menanggapi pembacaan pantun dan syair.

Gambaran pelaksanaan pembelajaran menulis pantun dan syair yaitu proses pembelajarannya menekankan pada kegiatan siswa 
dalam mengembangkan pemikiran anak dengan cara bekerja sendiri, mengembangkan sifat ingin tahu, menemukan sendiri, mengkontruksikan sendiri pengetahuan dan keterampilan barunya. Dengan demikian kegiatan yang dilakukan oleh siswa melalui latihan-latihan untuk memecahkan suatu masalah dapat teratasi.

\section{Kata kunci: Keterampilan menulis, model pembelajaran Contextual Teaching and Learning}

\section{ABSTRACT}

The use of relevant methods, strategies and approaches in learning is needed, including the use of contextual teaching and learning (CTL) learning models in Indonesian subjects in improving the poetry writing skills and the fifth grade students' poetry at the Islamic Elementary School of Ma'arif Candran Godean academic year 2016-2017. The use of contextual teaching and learning (CTL) learning has the potential to develop the realm of process knowledge and skills and develop students' attitudes, values and creativity in solving problems related to their daily lives, through interaction with fellow friends and also developing social skills. Barriers to learning through contextual models in writing poetry include students having difficulty in composing sentences in rows of lines in the form of addition and contents that match the theme, in group work only dominated by students who have higher potential writing skills, students are less willing to express opinions in response to reading rhymes and poems. The description of the implementation of writing poetry learning, namely the learning process emphasizes on student activities in developing children's thinking by working on their own, developing curiosity, discovering for themselves, constructing their own new knowledge and skills. Thus the activities carried out by students through exercises to solve a problem can be overcome.

Keywords: $\quad$ writing skills, learning models, contextual teaching and learning. 


\section{A. PENDAhuluan}

Keterampilan berbahasa Indonesia dalam pembelajaran Bahasa Indonesia meliputi empat jenis keterampilan yakni, menyimak, berbicara, membaca dan menulis. Dalam kehidupan modern ini jelas bahwa keterampilan menulis tidak hanya penting dalam dunia pendidikan, tetapi juga penting untuk lingkungan masyarakat. Keterampilan menulis ini penting karena keterampilan menulis sangat dibutuhkan oleh setiap orang. Keterampilan menulis merupakan suatu ciri dari orang yang terpelajar atau bangsa yang terpelajar. Oleh karena itu sebagai bangsa terpelajar orang Indonesia harus mempunyai keterampilan menulis.

\begin{tabular}{|c|c|c|}
\hline $\begin{array}{c}\text { MENYIMAK } \\
\text { Langsung } \\
\text { Apresiatif } \\
\text { Reseptif } \\
\text { Fungsional }\end{array}$ & $\begin{array}{c}\text { Komunikasi } \\
\text { tatap muka }\end{array}$ & $\begin{array}{c}\text { BERBICARA } \\
\text { Langsung } \\
\text { Produktif } \\
\text { Ekspresif }\end{array}$ \\
\hline & $\begin{array}{c}\text { KETERAMPILAN } \\
\text { BERBAHASA }\end{array}$ & \\
\hline $\begin{array}{c}\text { MENULIS } \\
\text { Tak langsung } \\
\text { Produktif } \\
\text { Ekspresif }\end{array}$ & $\begin{array}{c}\text { Komunikasi } \\
\text { tidak tatap muka }\end{array}$ & $\begin{array}{c}\text { MEMBACA } \\
\text { Tak langsung } \\
\text { Apresiatif } \\
\text { Reseptif } \\
\text { Fungsional }\end{array}$ \\
\hline
\end{tabular}

Gambar 1. Keterampilan Berbahasa

Pembelajaran menulis permulaan sangat penting diajarkan di sekolah dasar agar anak-anak dapat terlibat kegiatan baca tulis. Semakin tinggi tingkat kelas semakin meningkat dan berkembang kemahiran dalam menulisnya. Keterampilan menulis tidak hanya diajarkan melalui penjelasan atau uraian-uraian semata. Keterampilan menulis lebih banyak diperoleh melalui latihan-latihan secara terus menerus. Daya imajinasi siswa masih terus berkembang seiring dengan pertumbuhan dan pertambahan usianya.

Salah satu cara mengembangkan apresiasi sastra kepada siswa adalah pengajaran pantun syair, dengan tujuan agar siswa memperoleh kesadaran yang lebih 
terhadap dirinya sendiri, orang lain dan lingkungan sekitar, memperoleh kenangan, memperoleh pengetahuan dan pengertian dasar tentang pantun dan syair yang perlu mendapat perhatian dan pengajaran disekolah adalah pemilihan bahan pengajaran dan penyajiannya.

Oleh sebab itu, penggunaan model Contextual Teaching and Learning (CTL) pada mata pelajaran Bahasa Indonesia dalam peningkatan keterampilan menulis pantun dan syair siswa kelas V di MI Ma'arif Candran Godean yang akan membantu guru dalam proses pembelajaran aktif. Karena model pembelajaran ini dalam langkah-langkahnya menerapkan konsep belajar yang mengaitkan antara materi yang diajarkan dengan situasi dunia nyata terutama dalam pembelajaran menulis pantun dan syair.

Apabila konsep pembelajaran tersebut dipahami oleh guru, maka upaya mendesain pembelajaran bukan menjadi beban, tetapi menjadi pekerjaan yang menantang. Konsep pembelajaran tersebut meletakkan landasan yang meyakinkan bahwa peranan guru tidak lebih dari fasilitator, suatu posisi yang sesuai dengan pandangan konstruktivistik. Selain itu proses belajar mengajar akan terasa lebih hidup dan lebih menyenangkan dibandingkan dengan model pembelajaran guru MI Ma'arif Candran yang pernah dipakai sebelumnya. Sehingga siswa dapat dengan mudah menuangkan gagasan-gagasan dan ide-idenya dalam keterampilan menulis ke dalam sebuah rangkaian kata-kata indah hingga menjadi tulisan yang dapat dinikmati.

\section{B. METODE PENELITIAN}

Metode penelitian yang penulis gunakan pada penelitian ini adalah deskriptif kualitatif. Penelitian deskriptif kualitatif merupakan metode yang penelitiannya menggunakan penjelasan atau deskripsi dari suatu peristiwa yang terjadi pada saat sekarang, dimana peneliti hanya menggambarkan peristiwa dan kejadian yang menjadi pusat perhatiannya yang kemudian dideskripsikan kedalam bentuk kata dan kalimat yang mengandung makna.

Penelitian ini penulis lakukan pada salah satu sekolah Madrasah Ibtidaiyah (MI) di Daerah Istimewa Yogyakarta yaitu Madrasah Ibtidaiyah Ma'arif Candran Godean Yogyakarta, yang dikhususkan hanya pada siswa kelas V saja.

Sedangkan subjek dari penelitian ini adalah guru mata pelajaran Bahasa Indonesia dan siswa kelas V Madrasah Ibtidaiyah Ma'arif Candran Godean Yogyakarta. Dan objek dari penelitian ini adalah implemetasi model Contextual Teaching and Learning 
(CTL) pada mata pelajaran Bahasa Indonesia dalam peningkatan keterampilan menulis pantun dan syair siswa kelas V di MI Ma'arif Candran Godean Yogyakarta yang akan membantu guru dalam proses pembelajaran aktif.

Proses pengumpulan data yang dilakukan dalam penelitian ini menggunakan beberapa metode antara lain adalah sebagai berikut :

Pertama, observasi. Observasi merupakan salah satu metode pengumpulan data yang paling ilmiah dan paling banyak digunakan. Metode ini tidak hanya digunakan pada dunia keilmuan tetapi juga sering digunakan dalam berbagai aktifitas kehidupan. Metode observasi ini dilakukan untuk mendapatkan data secara langsung mengenai kondisi dan proses pengimplemetasian metode model Contextual Teaching and Learning (CTL) pada mata pelajaran Bahasa Indonesia dalam peningkatan keterampilan menulis pantun dan syair siswa. Metode observasi ini juga digunakan untuk mengetahui apakah siswa memperoleh kesadaran yang lebih terhadap dirinya sendiri, orang lain dan lingkungan sekitar, memperoleh kenangan, memperoleh pengetahuan dan pengertian dasar tentang pantun dan syair yang perlu mendapat perhatian dan pengajaran disekolah.

Kedua, wawancara. Wawancara yang dilakukan pada penelitian ini adalah wawancara yag tidak terstruktur. Maksudnya adalah wawancara akan dilakukan jika saat dalam observasi dilakukukan, pada proses implementasi metode model Contextual Teaching and Learning (CTL) pada mata pelajaran Bahasa Indonesia tidak terdapat salah satu komponen yang terdapat pada prinsip Contextual Teaching and Learning (CTL) yang mana Contextual Teaching and Learning (CTL) adalah sebuah sistem yang menyeluruh yang terdiri dari bagian-bagian yang saling berhubung. Jika dalam observasi telah mengandung semua komponen, maka metode wawancara dapat diabaikan.

Ketiga, dokumentasi. Dokumentasi yang dilakukan pada penelitian ini menggunakan dokumentasi berupa foto-foto kejadian atau kegiatan saat penerapan model Contextual Teaching and Learning (CTL) pada mata pelajaran Bahasa Indonesia. Metode ini digunakan untuk membantu penulis mengingat dan mengumpulkan data-data observasi. Dokumentasi juga dapat digunakan untuk mengumpulkan data-data yang bersifat dokumenter, seperti kegiatan pelaksanaan mata pelajaran Bahasa Indonesia dalam peningkatan keterampilan menulis pantun dan syair siswa, yang meliputisilabus pembelajaran, RPP, dan dokumen lain yang berhubungan dengan proses pelaksanan kegiatan. 
Isniarni

\section{HASIL PENELITIAN DAN PEMBAHASAN}

\section{Pentingnya kegiatan menulis}

Salah satu keterampilan yang harus dikuasai siswa sekolah dasar adalah keterampilan menulis. Menurut Heaton (1975:127) Menulis adalah kegiatan menyusun kata-kata kalimat secara benar sesuai dengan kaidah tata bahasa kemudian menghubung-hubungkan kalimat tersebut sehingga terbentuk suatu tulisan yang saling berhubungan yang dapat mengkomunikasikan pikiran dan ide penulis tentang suatu topik. ${ }^{1}$

Dalam pengertian menulis yaitu melahirkan pikiran atau gagasan (seperti mengarang, membuat surat) dengan tulisan. Menulis merupakan kegiatan yang bisa melahirkan kreativitas seseorang.

Keterampilan menulis merupakan salah satu keterampilan berbahasa yang dipelajari oleh siswa disekolah. Melalui keterampilan menulis, siswa dituntut untuk kreatif dan aktif dalam berfikir dan beraktifitas sebanyak mungkin menuangkan ide-ide yang dimilikinya kedalam bahasa tulis. Menulis merupakan kegiatan yang mengasyikkan bahkan menulis bisa disebutkan sebagai kegiatan kreatif yang akan mengantarkan siswa menjadi orang yang sukses dibidang karya tulis.

Menulis merupakan keterampilan berbahasa yang dimiliki dan digunakan manusia sebagai alat komunikasi secara tidak langsung yang memiliki tahapan dalam proses penulisannya dan menjadikan seseorang mendapatkan kesuksesan dalam membuat tulisan, proses melukiskan lambang-lambang yang dapat dipahami dan melahirkan pikiran atau gagasan dengan penggunaan bahasa secara ekspresif berdasarkan kreativitas.

Kemampuan menulis tidak dapat diperoleh secara alamiah, tetapi melalui proses belajar mengajar. Menulis merupakan kegiatan yang sifatnya berkelanjutan sebagai pembelajarannya pun perlu dilakukan secara berkesinambungan sejak sekolah dasar. Hal ini didasarkan pada pemikiran bahwa menulis merupakan kemampuan dasar sebagai bekal belajar menulis dijenjang berikutnya. Oleh karena itu, pembelajaran menulis perlu mendapat perhatian yang optimal khususnya di Sekolah Dasar sehingga apabila kemampuan menulis ini telah dikuasai diharapkan dijenjang berikutnya kemampuan menulis mereka mampu menghasilkan karya tulisan yang produktif dimasa yang akan datang. Tetapi pada kenyataannya banyak

1. J.B. Heaton, Writing English Language test (New York: Longman, 1975), hlm. 127. 
sekali kesulitan menulis yang dialami oleh siswa MI. Kesulitan menulis anak tersebut antara lain tak mampu berkomunikasi secara tertulis. Kerap ditemukan kesalahan dalam ejaan, tanda baca, dan pemakaian huruf kapital, lalu bentuk huruf yang ditulis sangat buruk. Anak bersangkutan terkadang bisa menulis dengan lebih baik bila diberikan waktu yang lama bisa diakibatkan gangguan konsentrasi dan pemusatan perhatian, memori visual dan koordinasi motorik halus.

Keterampilan menulis dapat diklasifikasikan berdasarkan dua sudut pandang yang berbeda. Sudut pandang tersebut adalah kegiatan atau aktifitas dalam melaksanakan keterampilan menulis dan hasil produk menulis itu. Klasifikasi keterampilan menulis berdasarkan sudut pandang kedua menghasilkan pembagian produk menulis atau empat kategori yaitu (1) karangan narasi, (2) eksposisi, (3) deskripsi, (4) argumentasi.

\section{Pantun dan Syair}

a. Pantun

Pantun merupakan puisi melayu asli yang sudah mengakar lama di budaya masyarakat. Pantun salah satu jenis karya sastra yang lama. Misalnya dalam masyarakat Sunda dikenal dengan wawangsalan, paparikan, sisindiran dan sesebred. Dalam masyarakat Jawa dikenal dengan pantun ludruk dan gandrung. Dalam masyarakat Mandailing dikenal dengan ende-ende. Bahkan disebagian daerah Sumatera, masyarakat Minangkabau menggunakan pantun sebagai pembuka acara di perayaan-perayaan. Selain dibaca, pantun juga kerap dinyanyikan.

Lazimnya puisi hanya terdiri atas 4 larik (baris) bersajak ab-ab atau aa-aa. Pada awal mulanya pantun merupakan sastra lisan, tapi kini pantun juga ada dalam bentuk tulisan. Keseluruhan bentuk pantun hanyalah berupa sampiran dan isi. Sampiran terletak pada baris pertama dan kedua dan biasanya tidak berhubungan secara langsung dengan bagian kedua serta biasanya hanya mengantarkan rima/ sajak. Kerap kali berkaitan dengan alam (menceritakan budaya agraris masyarakat pendukungnya). Baris ketiga dan keempat ialah bagian isi yang merupakan tujuan dari puisi tersebut.

Dalam Kamus Istilah Sastra (1994:143), pantun adalah jenis puisi lama yang terdiri atas empat larik dengan rima akhir a-b-a-b. Tiap larik biasanya 
berisi empat kata. Dua larik pertama merupakan sampiran, sedang larik ketiga dan keempat mengandung isi. ${ }^{2}$

Ciri-ciri pantun dapat dilihat berdasarkan bentuknya. Ciri-ciri ini tidak boleh diubah karena jika diubah pantun tersebut akan menjadi seloka, gurindam atau bentuk puisi lama lainnya. Ciri-ciri pantun adalah sebagai berikut:

- Tiap bait terdiri atas empat larik (baris)

- Tiap baris terdiri atas 8 sampai 12 suku kata

- Rima akhir setiap baris adalah a-b-a-b

- Baris pertama dan kedua merupakan sampiran

- Baris ketiga dan keempat merupakan isi

Suroto (1989:44-45) membagi pantun menjadi dua bagian yaitu menurut isinya dan menurut bentuknya atau susunannya.

Menurut isinya: (1) pantun anak-anak biasanya berisi permainan, (2) pantun muda mudi biasanya berisi percintaan, (3) pantun orang tua biasanya berisi nasihat atau petuah. Itulah sebabnya pantun ini disebut juga pantun nasihat, (4) pantun jenaka biasanya berisi sindiran sebagai bahan kelakar, (5) pantun teka teki.

Menurut bentuknya atau susunannya: (1) pantun berkait, yaitu pantun yang selalu berkaitan antara bait satu dengan bait kedua, bait kedua dengan bait ketiga dan seterusnya. Adapun susunan kaitannya adalah baris kedua bait pertama menjadi baris pertama pada bait kedua, baris keempat bait pertama dijadikan baris ketiga pada bait kedua dan seterusnya. (2) pantun kilat, sering disebut juga karmina, ialah pantun yang terdiri atas dua baris, baris pertama merupakan sampiran sedangkan baris kedua merupakan isi. Sebenarnya asal mula pantun ini juga terdiri atas empat baris, tetapi karena barisnya pendekpendek maka seolah-olah kedua baris pertama diucapkan sebagai sebuah kalimat, demikian pula kedua baris yang terakhir.

Contoh pantun nasihat

Buat apa membeli jamu

Kalau tidak bisa dimakan

2. Abdul Rozak Zaidan, Anita K Rustapa, dan Hani'ah, Kamus Istilah Sastra (Jakarta: Balai Pustaka, 1994), hlm. 143. 
Buat apa mempunyai ilmu

Kalau engkau tidak mengamalkan

Contoh pantun anak-anak

Ekor panjang si ikan pari

Jenur satu di atas pohon

Adik menangis sepanjang hari

Minta ibu belikan balon

Contoh pantun kilat

Indahnya taman, duduknya di papan

Tanda iman, lakunya sopan

b. Syair

Syair adalah salah satu sastra puisi lama. Kata syair berasal dari bahasa Arab syu'ur yang artinya "perasaan", kemudian syu'ur berkembang menjadi syi'ru yang artinya puisi dalam pengetahuan umum. Syair merupakan puisi lama yang terdiri atas empat baris dimana keseluruhan baris adalah isi/maksud. Dalam perkembangannya syair tersebut mengalami perubahan dan modifikasi sehingga menjadi khas Melayu, tidak lagi mengacu pada tradisi sastra negeri Arab. Penyair yang berperan besar dalam membentuk syair khas Melayu adalah Hamzah Fansuri dengan karyanya antara lain: syair perahu, syair burung Pingai, syair dagang dan syair sidang fakir.

Ciri-ciri syair antara lain:

- Setiap baris terdiri dari empat baris

- Setiap baris terdiri atas 8-14 suku kata

- Bersajak a-a-a-a

- Semua baris adalah isi

- Bahasanya biasanya kiasan. 
Contoh Syair Abdul Muluk

Berhentilah kisah raja Hindustan

Tersebutlah pula suatu perkataan

Abdul Hamit syah padaku sultan

Abdul Muluk putra baginda

Besarlah sudah bangsawan muda

Cantik majelis usulnya syahdam

Tiga belas tahun umurnya ada

Paras elok amat sempurna

Petah menjelis bijak laksana

Memberi hati bimbang gulana

Kasih kepadanya mulia dan hina

\section{Model Pembelajaran Contextual Teaching and Learning}

Pembelajaran menurut Dimyati dan Mudjiono (2006:17) menjabarkan bahwa pembelajaran adalah kegiatan guru secara terprogram dalam desain instruksional, untuk membuat siswa belajar secara aktif, yang menekankan pada penyediaan sumber belajar. ${ }^{3}$ Dan pembelajaran merupakan suatu proses yang dilakukan oleh individu untuk memperoleh suatu perubahan perilaku yang baru secara keseluruhan, sebagai hasil dari pengalaman individu itu sendiri dalam interaksi dengan lingkungannya.

Penggunaan pembelajaran kontekstual memiliki potensi tidak hanya untuk mengembangkan ranah pengetahuan dan keterampilan proses, tetapi juga untuk mengembangkan sikap, nilai serta kreativitas siswa dalam memecahkan masalah yang terkait dengan kehidupan mereka sehari-hari melalui interaksi dengan sesama teman misalnya melalui pembelajaran kooperatif, sehingga mengembangkan keterampilan sosial.

3. Dimyati dan Mudjiono, Belajar dan Pembelajaran (Jakarta: PT. Asdi Mahasatya, 2006), hlm. 17. 
Elaine B. Johnson (2002:65), Contextual Teaching and Learning (CTL) adalah sebuah sistem yang menyeluruh yang terdiri dari bagian-bagian yang saling berhubung. Jika bagian-bagian itu terjalin satu sama lain, maka akan dihasilkan pengaruh yang melebihi hasil yang diberikan bagian-bagiannya secara terpisah. Bagian-bagian CTL yang terpisah melibatkan proses-proses yang berbeda, yang ketika digunakan secara bersama-sama, memampukan para siswa membuat hubungan yang menghasilkan makna. Setiap bagian CTL yang berbeda-beda ini memberikan sumbangan dalam menolong siswa memahami tugas sekolah. Secara bersama-sama, mereka membentuk suatu sistem yang memungkinkan para siswa melihat makna di dalamnya, dan mengingat materi akademik. ${ }^{4}$

Sistem CTL mencakup delapan komponen berikut ini: (1) membuat keterkaitan-keterkaitan yang bermakna, (2) melakukan pekerjaan yang berarti, (3) melakukan pembelajaran yang diatur sendiri, (4) bekerja sama, (5) berpikir kritis dan kreatif, (6) membantu individu untuk tumbuh dan berkembang, (7) mencapai standar yang tinggi, (8) menggunakan penilaian autentik. ${ }^{5}$

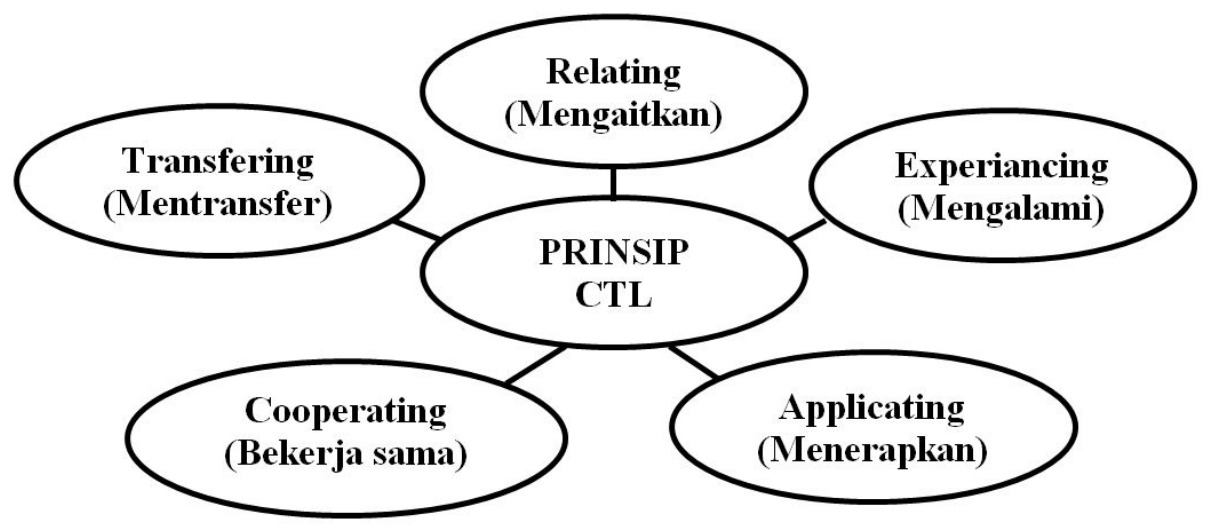

Gambar 2. Prinsip CTL

Prinsip-prinsip dalam CTL yang harus diketahui adalah(1)CTLmencerminkan prinsip kesaling-bergantungan. Kesaling-ketergantungan mewujudkan diri, misalnya ketika para siswa bergabung untuk memecahkan masalah dan ketika para

4. Johnson Elaine B, Contextual Teaching and Learning: Menjadikan Kegiatan BelajarMengajar Mengasyikkan dan Bermakna (Bandung: Mizan Learning Center, 2008), hlm. 65 .

5. Ibid., hlm. 66 . 
mengadakan pertemuan dengan rekannya. Hal ini tampak jelas ketika subjek yang berbeda dihubungkan, dan ketika kemitraan menggabungkan sekolah dengan dunia bisnis dan komunitas. (2) CTL mencerminkan prinsip diferensiasi. Diferensiasi menjadi nyata ketika CTL manantang para siswa untuk saling menghormati keunikan masing-masing, untuk menghormati perbedaan-perbedaan, untuk menjadi kreatif, untuk bekerja sama, untuk menghasilkan gagasan dan hasil baru yang berbeda, dan untuk menyadari bahwa keragaman adalah tanda kemantapan dan kekuatan. (3) CTL mencerminkan prinsip pengorganisasian diri. Pengorganisasian diri terlihat ketika para siswa mencari dan menemukan kemampuan dan minat mereka sendiri yang berbeda, mendapat manfaat dari umpan balik yang diberikan oleh penilaian autentik, mengulas usaha-usaha mereka dalam tuntunan tujuan yang jelas dan standar yang tinggi, dan berperan serta dalam kegiatan-kegiatan yang berpusat pada siswa yang membuat hati mereka bernyanyi.

Pembelajaran kontekstual atau Contextual Teaching and Learning (CTL) merupakan suatu proses pendidikan yang holistik dan bertujuan membantu siswa siswi untuk memahami makna materi pelajaran yang dipelajarinya dengan mengaitkan materi tersebut dengan konteks kehidupan kereka seharihari (konteks pribadi, sosial dan kultural), sehingga siswa memiliki pengetahuan ataupun keterampilan yang secara fleksibel dapat diterapkan (ditransfer) dari satu permasalahan ke permasalahan lain.

CTL atau Contextual Teaching and Learning adalah konsep belajar yang membantu guru mengaitkan antara materi yang diajarkan dengan situsi dunia nyata siswa yang mendorong siswa membuat hubungan antara pengetahuan yang dimilikinya dengan penerapannya dalam kehidupan sehari-hari.

\section{Komponen Pendekatan Contextual Teaching and Learning}

Menurut Depdiknas, untuk penerapannya pendekatan kontekstual (CTL) memiliki tujuah komponen utama, yaitu konstruktivisme (constructivism), menemukan (Inquiry), bertanya (Questioning), masyarakat-belajar (Learning Community), pemodelan (modeling), refleksi (reflection), dan penilaian yang sebenarnya (Authentic). 


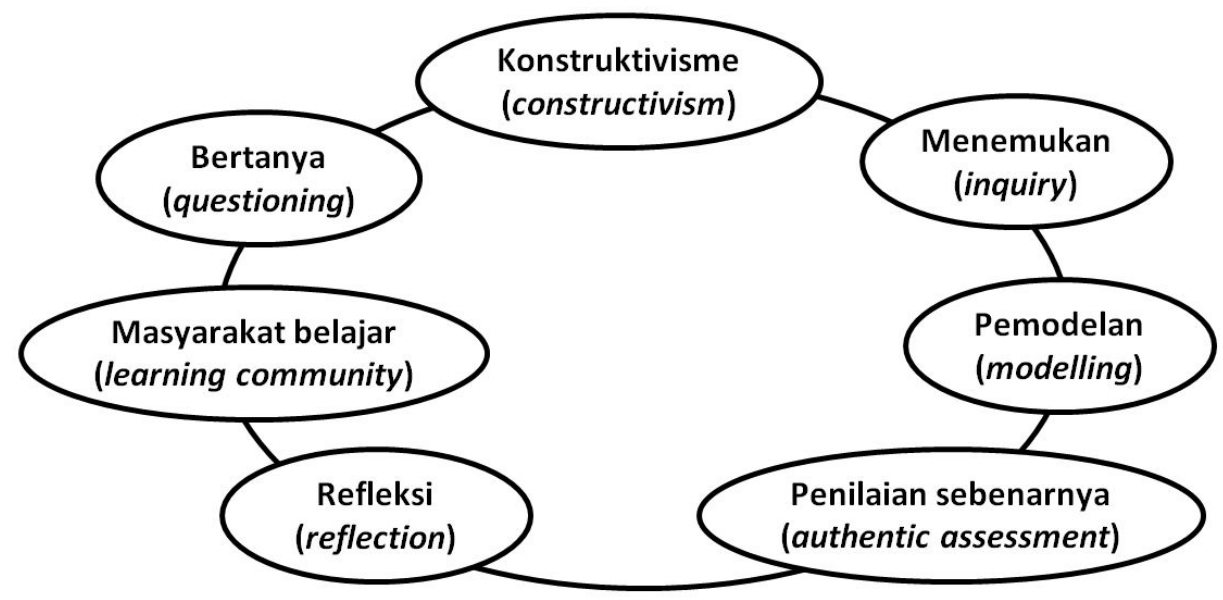

Gambar 3. Komponen CTL

Seperti yang ditunjukan pada Gambar 2, pembelajaran kontekstual ini memiliki 7 komponen utama yakni sebagai berikut: (1) Konstruktivisme, merupakan landasan berpikir pendekatan CTL. Dalam konstruktivisme pengetahuan siswa dibangun secara bertahap dan hasil yang diperoleh melalui konteks yang terbatas. Pengetahuan yang diperoleh tidak hanya seperangkat fakta, konsep atau kaidah yang siap diambil dan diingat belaka, melainkan siswa harus mengkonstruksi sendiri pengetahuan tersebut barulah kemudian memberi makna melalui pengalaman yang nyata sehingga siswa menjadi pusat kegiatan. (2) Inquiry (menemukan sendiri), merupakan bagian terpenting dalam pembelajaran yang menggunakan pendekatan kontekstual. Pengetahuan dan keterampilan yang diperoleh siswa dengan cara menemukan sendiri. Oleh sebab itu proses pembelajaran yang dirancang guru harus berbentuk kegiatan yang merujuk pada kegiatan menemukan. Langkah-langkah pembelajarannya dimulai dengan merumuskan masalah, mengamati, menganalisis dan mengkomunikasikannya. (3) Questioning (bertanya), merupakan strategi yang utama dalam pendekatan kontekstual. Bertanya dalam pembelajaran dipandang sebagai kegiatan guru untuk mendorong, membimbing dan menilai kemampuan berpikir siswa. (4) Learning community (masyarakat belajar), merupakan salah satu teknik dalam pendekatan kontekstual. Dengan teknik ini pembelajaran diperoleh dari kerjasama dengan orang lain. Hasil belajar diperoleh melalui sharing antar teman, antar kelompok dan antara yang tahu ke yang belum tahu. Kegiatan ini akan terjadi bila tidak ada pihak yang dominan dalam komunikasi, tidak ada pihak yang merasa segan 
untuk bertanya dan tidak ada pihak yang menganggap dirinya paling tahu. Setiap pihak harus merasa bahwa setiap orang lain memiliki pengetahuan, pengalaman atau keterampilan yang berbeda yang perlu dipelajari. (5) Modelling (pemodelan), maksud dari pemodelan adalah pembelajaran dilakukan dengan menampilkan model yang bisa dilihat, dirasa dan bahkan bisa ditiru oleh siswa. Dalam praktiknya guru bukan merupakan satu-satunya model. Karena model yang disampaikan akan menjadi standar kompetensi yang akan dicapai, maka jika guru tidak mampu menjadi model jangan sekali-kali memaksakan diri. Guru dapat mendatangkan model dari luar. Model tersebut bisa dari siswa yang dianggap mampu, atau para pakar ke dalam kelas. (6) Reflection (refleksi), adalah cara berfikir tentang apaapa yang sudah kita lakukan dimasa lalu. Refleksi merupakan respon terhadap kejadian, aktifitas atau pengetahuan yang baru diterima. Tujuan dari kegiatan refleksi ini adalah untuk melihat sudah sejauh mana pengetahuan yang dibangun sebelumnya dapat mengendap di benak siswa. Oleh karena itu kegiatan refleksi ini harus selalu dilakukan sebelum guru mengakhiri proses pembelajaran untuk setiap kali pertemuannya. (7) Authentic assessment (penilaian yang sebenarnya), assesmen adalah proses pengumpulan berbagai data yang bisa memberikan gambaran perkembangan belajar siswa. Kegiatan ini perlu dilakukan guru untuk mengetahui dan memastikan bahwa siswa telah mengalami proses pembelajaran dengan benar. Dan apabila dari hasil assesmen ini diketahui siswa mengalami kesulitan dalam menguasai kompetensi, maka guru harus segera mengambil tindakan yang tepat agar siswa dapat menguasai kompetensi yang telah ditetapkan.

Banyak cara efektif untuk mengaitkan pengajaran dan pembelajaran dengan konteks situsi sehari-hari siswa. Oleh sebab itu, perlu menyoroti metode yang paling efektif untuk menyatukan isi akademik dan konteks pengalaman pribadi siswa, Ada enam metode yaitu; (1) Ruang kelas tradisional yang mengaitkan materi dengan konteks siswa, (2) Memasukkan materi dari bidang lain dalam kelas, (3) Mata pelajaran terpisah, tetapi mencakup topik-topik yang saling berhubungan, (4) Mata pelajaran gabungan yang menyatukan dua atau lebih disiplin, (5) Menggabungkan sekolah dan pekerjaan (pembelajaran berbasis pekerjaan, jalur karir, pengalama kerja berbasis sekolah), (6) Metode kuliah kerja nyata atau penerapan terhadap hal-hal yang dipelajari di sekolah ke masyarakat.

Guru berperan dalam menentukan pembelajaran bahasa Indonesia. Oleh karena itu, guru dituntut untuk menguasai bahasa Indonesia dan pembelajarannya sehingga menjadi mata pelajaran yang menarik bagi siswa. Kemenarikan ini 
akhirnya membawa siswa ke tingkat komunikasi yang lancar. Dalam pembelajaran bahasa, banyak strategi pembelajaran yang tersedia. Namun, mengapa banyak guru bahasa Indonesia yang masih kesulitan dalam memvariasikan strategi pembelajaran bahasa Indonesia. Maka banyak yang berkutat dengan ceramah, diskusi dan penugasan. Padahal hal tersebut merupakan teknik pengelolaan kelas. Teknik adalah cara kongkrit yang dipakai saat proses pembelajaran berlangsung. Guru dapat berganti teknik meskipun dalam koridor metode yang sama.

Adapun langkah-langkah dalam pembelajaran CTL dalam kelas secara garis besar dapat digambarkan sebagai berikut: (1) Mengembangkan pemikiran anak dengan cara bekerja sendiri, menemukan sendiri, mengkonstruksikan sendiri pengetahuan dan keterampilan barunya, (2) Melaksanakan sejauh mungkin kegiatan inquiri untuk pada topik permasalahan, (3) Mengembangkan sifat ingin tahu siswa dengan bertanya, (4) Menciptakan masyarakat belajar (belajar dalam kelompok-kelompok), (5) Menghadirkan model sebagai contoh pembelajaran, (6) Melakukan refleksi di akhir pertemuan pembelajaran, (7) Melakukan evaluasi dengan cara yang tepat dan sesuai prosedur yang direncanakan.

Guru juga membantu siswa-siswa berkembang dengan menyibukkan mereka dalam tugas-tugas yang mendorong mereka berhubungan dengan masyarakat. Contoh-contoh berikut menunjukkan beraneka macam cara yang dilakukan oleh guru-guru di kelas untuk menghubungkan mata pelajaran akademik dengan konteks siswa itu sendiri. Contoh-contoh pengaitan dalam CTL di kelas:

- Di kelas yang sudah tinggi, para guru mendorong siswa untuk membaca, menulis dan berfikir secara kritis dengan meminta mereka untuk fokus pada persoalan-persoalan kontroversial di lingkungan atau masyarakat mereka. Kelas dibagi menjadi empat atau lima kelompok. Setiap kelompok memilih sebuah persoalan kontroversial dan menelitinya. Mereka melakukan penelitian di perpustakaan, melakukan survei lapangandan mewancarai pejabat setempat mengenai persoalan yang sedang diteliti. Mereka menyajikan penemuanpenemuan dalam bentuk presentasi disertai foto, gambar, diagram dan grafik. Mereka menyampaikan penemuan-penemuan tersebut di depan khalayak yang terdiri dari teman sekelas dan para orangtua.

- Anak-anak di sekolah dasar meneliti beberapa pelukis. Dalam kelas, mereka menghabiskan sebagian besar waktu untuk menggambar sesuai dengan gaya pelukis yang sedang dipelajari dengan menggunakan krayon dan kapur tulis. 
Pada akhir pelajaran kesenian, setiap anak memilih seorang pelukis yang karyanya paling disenangi untuk ditiru. Lalu anak-anak tersebut pergi ke kantin seakolah saat sedang kosong dan mendapati kertas kosong yang sangat panjang dan luas tergantung disana. Setiap siswa melukis sebuah gambar di kertas tersebut, meniru karya pelukis yang sudah mereka tentukan. Saat semua anak selesai menggambar, para siswa mundur untuk melihat dan membicarakan karya mereka. Mereka termotivasi saat mengetahui lukisan mereka akan menghiasi kantin selama dua minggu.

- Standar pendekatan CTL untuk mempelajari kesusastraan adalah memberikan satu pertanyaan untuk didiskusikan oleh para siswa sebelum mereka membaca tugas yang akan diberikan. Pertanyaan tersebut berhubungan dengan gambaran atau situasi yang akan ditemui oleh siswa pada bacaan yang ditugaskan. Membicarakan terlebih dahulu mengenai gagasan-gagasan di balik tugas yang akan diberikan membuka jalan bagi para siswa untuk melihat bahwa kesusastraan berhubungan dengan kehidupan mereka. Jika kemudian mereka membaca teks tersebut dengan cermat, menjadi akrab dengan materinya, mereka siap untuk menerapkan apa yang mereka pelajari pada puisi, cerita pendek, pantun, syair, atau esai dengan konteks kehidupan sehari-hari.

Langkah-langkah CTL untuk membangun keterkaitan didalam kelas, mengajak para guru untuk membuat kelas mereka menjadi suatu tempat penuh makna bagi para siswa dengan cara membangun keterkaitan yakni:

- Pikirkan bagaimana para siswa mendapatkan informasi di kelas anda. Apakah anda menghabiskan sebagian besar waktu untuk memberi informasi, menjelaskan, memberi tahu? Saat anda mengajar, apakah anda sering berhenti dan mengajak para siswa untuk mendiskusikan apa yang sudah anda jelaskan atau bertanya? Apakah pelajaran disampaikan dengan cara yang bervariasi agar mengena pada gaya belajar yang berbeda? Apakah anda mendorong para siswa mempergunakan seluruh anggota tubuh dalam proses belajar?

- Bertanyalah pada diri anda sendiri: Apa tujuan utama mata pelajaran ini? Atau Apa tujuan dari pelajaran kali ini? Tujuan apa yang ingin saya capai dengan menggunakan pelajaran ini dikelas? Tulislah hal-hal spesifik yang anda ingin siswa anda ketahui dan dapat dilaksanakan. Gunakanlah kata kerja aktif.

- Uji isi mata pelajaran. Mengapa anda memberikan pelajaran tertentu? Apakah mata pelajaran anda memberi para siswa waktu untuk ikut serta secara aktif 
dalam proses belajar? Apakah mereka memiliki waktu untuk bertanya, bekerjasama mengerjakan tugas, memecahkan masalah dan menemukan hubungan antara ide-ide baru dan hal-hal yang sudah mereka ketahui? Beri mereka waktu untuk menemukan makna. Dorong mereka agar menyelidiki materi dengan lebih mendalam.

- Apakah pelajaran-pelajaran tersebut mengajak penting? Apakah pelajaran tersebut mengajak para siswa dalam memproduksi barang-barang nyata untuk orang lain? Apakah pelajaran tersebut mencerminkan kesadaran akan pengalaman masa lalu dan situasi rumah para siswa sendiri?

- Apakah anda menggunakan beberapa metode "penilaian autentik" (authentic assessment)" yang mensyaratkan para siswa agar giat belajar sekaligus mampu mempertunjukkan keterampilan? Tugas-tugas autentik adalah tugas-tugas yang secara alami berhubungan langsung dengan sebuah mata pelajaran, Mereka meniru pekerjaan yang sesungguhnya dilakukan oleh para praktisi.

- Apakah para siswa mendapat kesempatan untuk menggunakan pemikiran tingkat tinggi-untuk berpikir kritis dan kreatif? Bagaimana cara anda mengajar para siswa seni dari pemikiran kritis? Bagaimana cara anda menanamkan pemikiran kreatif?

- Sudahkah anda mengajak para siswa untuk bekerja sama sehingga mereka dapat mengambil manfaat dari bakat siswa lain? Apakah bekerja sama mengajarkan untuk saling menghormati dan kemungkinan untuk berbagi kesuksesan? Apakah dengan bekerja sama tersebut para siswa belajar untuk mendengarkan pendapat orang lain?

- Apakah para siswa yang mengambil kelas anda mendapat kesempatan untuk menggunakan fasilitas-fasilitas pendukung, mengumpulkan dan mengatur informasi, bekerja dengan teknologi, meneliti sistem?

- Apakah kelas anda menyediakan lingkungan yang aman, terjamin dan ramah?

- Apakah anda sering bertatap muka dengan setiap siswa? Cara lain apa yang anda gunakan untuk memperlihatkan kepada para siswa bahwa anda benarbenar peduli kepada mereka dan bersedia membantu mereka?

\section{KESIMPULAN}

Penggunaan model Contextual Teaching and Learning (CTL) pada mata pelajaran Bahasa Indonesia dalam peningkatan keterampilan menulis pantun dan 
syair siswa dapat membantu guru dalam proses pembelajaran aktif. Hal ini disebabkan karena langkah-langkah pada model pembelajaran ini menerapkan konsep belajar yang mengaitkan materi yang diajarkan kedalam kondisi nyata. Selain itu proses belajar mengajar akan terasa lebih hidup dan lebih menyenangkan dibandingkan dengan metode umum (ceramah, diskusi dan penugasan). Siswa dapat dengan mudah menuangkan gagasan-gagasan dan ide-idenya dalam keterampilan menulis ke dalam sebuah rangkaian kata-kata indah hingga menjadi tulisan yang dapat dinikmati. Guru sangat berperan dalam menentukan pembelajaran bahasa Indonesia. Oleh karena itu, guru dituntut untuk menguasai bahasa Indonesia dan pembelajarannya sehingga menjadi mata pelajaran yang menarik bagi siswa. Langkah-langkah pada model Contextual Teaching and Learning (CTL) dapat membangun keterkaitan didalam kelas yang mampu mengajak para guru untuk membuat kelas mereka menjadi suatu tempat penuh makna bagi para siswa dengan cara membangun keterkaitan antara materi yang diajarkan kedalam kondisi nyata.

\section{E. DAFTAR PUSTAKA}

Dimyati, dan Mudjiono. Belajar dan Pembelajaran. Jakarta: PT. Asdi Mahasatya, 2006.

Elaine B, Johnson. Contextual Teaching and Learning: Menjadikan Kegiatan Belajar-Mengajar Mengasyikkan dan Bermakna. Bandung: Mizan Learning Center, 2008.

Heaton, J.B. Writing English Language test. New York: Longman, 1975.

Zaidan, Abdul Rozak, Anita K Rustapa, dan Hani'ah. Kamus Istilah Sastra. Jakarta: Balai Pustaka, 1994. 